\title{
The Biological Responses of Axotomized Adult Motoneurons to Brain-derived Neurotrophic Factor
}

\author{
Qiao Yan, Christine Matheson, Oscar T. Lopez, and James A. Miller \\ Department of Neurobiology, Amgen, Inc., Amgen Center, Thousand Oaks, California 91320
}

\begin{abstract}
Recent studies showed that brain-derived neurotrophic factor (BDNF) prevents developing motoneurons from naturally occurring and axotomy-induced cell death. Here we examined whether adult motoneurons retain responsiveness to BDNF. Consistent with previous studies, we found that adult spinal and brainstem motoneurons expressed the mRNA of BDNF receptor, trkB. In addition, the trkB immunoreactivities were readily detected in the adult spinal and brainstem motoneurons. We then demonstrated that axotomized adult motoneurons responded to exogenous BDNF. BDNF administered locally markedly attenuated the lesion-induced decrease of ChAT immunoreactivity and activity and enhanced the lesion-induced reexpression of low-affinity NGF receptor immunoreactivity in adult facial motoneurons. Furthermore, we found BDNF administered subcutaneously, intravenously, and into the cerebral ventricle attenuated the lesion-induced decrease of ChAT immunoreactivity in adult facial motoneurons in a dose-dependent fashion. Our data indicate that adult motoneurons retain their responsiveness to BDNF, suggesting that BDNF may be useful as a therapeutic agent for adult motoneuron disease.
\end{abstract}

[Key words: trkB receptor, ChAT, low-affinity NGF receptor, p75, facial nerve, axotomy]

Although NGF, the prototypical neurotrophin, appears not to promote motoneuron survival (Oppenheim et al., 1982; Miyata et al., 1986; Yan et al., 1988; Oppenheim et al., 1992), recent evidence suggests that BDNF (Leibrock et al., 1989), a member of the neurotrophin family, is a trophic factor for motoneurons. Treatment of chick embryos with BDNF prevents the death of approximately one-third of the motoneurons in the lumbosacral spinal cord that normally die during the period of naturally occurring cell death (Oppenheim et al., 1992). In the same study, BDNF prevents the death of lumbosacral spinal motoneurons induced by the deafferentation of these neurons, achieved by the removal of a few segments of thoracic neural tube at embryonic day 2. In neonatal rats, BDNF applied locally in Gelfoam implants reduces the loss of lumbar spinal motoneurons (Yan et al., 1992) and facial motoneurons (Sendtner et al., 1992; Koliatsos et al., 1993; Yan et al., 1993) induced by nerve tran-

\footnotetext{
Received Oct. 25, 1993; revised Dec. 29, 1993; accepted Jan. 13, 1994.

We thank Dr. E. M. Johnson, Jr., for 192-IgG antibody, Drs. S. Feinstein and M. Radeke for anti-trkB peptide antibody, and J. Hogan for purification of BDNF. Wc thank Drs. E. M. Johnson, Jr., A. Wclcher, and F. Collins for helpful comments on the manuscript.

Correspondence should be addressed to Qiao Yan, Ph.D., Department of Neurobiology, Amgen, Inc., 1840 DeHavilland Drive, Thousand Oaks, CA 91320.

Copyright (c) 1994 Society for Neuroscience $0270-6474 / 94 / 145281-11 \$ 05.00 / 0$
}

section. It is interesting that although BDNF fails to promote the survival of purified embryonic chick motoneurons in vitro (Arakawa et al., 1990), BDNF is shown to be a potent survivalpromoting factor for cultured rat motoneurons (Henderson et al., 1993).

It appears that BDNF may act on motoneurons in both targetderived and non-target-derived fashions. Northern blot and in situ hybridization studies demonstrate that BDNF mRNA is expressed in limb bud and postnatal muscle (Henderson et al., 1993; Koliatsos et al., 1993). BDNF mRNA expression is upregulated in adult muscle by denervation (Koliatsos et al., 1993). $\mathrm{BDNF}$ in muscle can act as a target-derived neurotrophic factor for motoneurons. BDNF-like immunoreactivity has been demonstrated in Schwann cells in vitro (Acheson et al., 1991; Meyer et al., 1992), while in vivo BDNF levels are barely detectable in Schwann cells. However, its level dramatically increases in Schwann cells in the distal region of axotomized sciatic nerve (Meyer et al., 1992). Thus, Schwann cell-derived BDNF might be an important source of this factor during the regeneration of motoneurons. In addition, BDNF mRNA is expressed by a subset of medium- to large-size DRG neurons in rodents during development (Ernfors and Persson, 1991; Schecterson and Bothwell, 1992). It is possible that such BDNF-expressing neurons are proprioceptive neurons that form monosynapses on motoneurons. Motoneurons may receive BDNF from these afferent fibers. The expression of BDNF by a variety of eells in contact with motoneurons and the profound survival-promoting activity of BDNF on developing motoneurons indicate that BDNF may serve as a motoneuron trophic factor.

The biological effects of neurotrophins are believed to be mediated through specific cell surface receptors. One type of receptor for the neurotrophins has been identified as tyrosine kinase receptors coded by the trk family of proto-oncogenes. Studies indicate that NGF specifically interacts with trkA (Hempstead et al., 1991; Kaplan et al., 1991; Klein et al., 1991a), BDNF with $t r k B$ (Klein et al., 1991 b; Soppet et al., 1991; Squinto et al., 1991), and NT-3 mainly with $t r k \mathrm{C}$ but, at least in some circumstances, also with $t r k \mathrm{~A}$ and $t r k \mathrm{~B}$ (Lamballe et al., 1991). The expression of specific trk receptors by various cell populations is indicative of a cell's responsiveness to a particular neurotrophin. The fact that motoneurons express $t r k \mathrm{~B}$ mRNA (Ernfors et al., 1992; Merlio et al., 1992; Yan et al., 1993) is consistent with the biological responsiveness of developing motoneurons to BDNF (Oppenheim et al., 1992; Sendtner et al., 1992; Yan et al., 1992; Koliatsos et al., 1993). In addition to the $t r k$ family receptors, all the neurotrophins bind to the lowaffinity NGF receptor ( $75^{\text {LNGFR }}$ ) with similar affinity (Rodriguez-Tébar et al., 1990; Hallböök et al., 1991; Soppet et al., 
1991; Squinto et al., 1991), suggesting that the $p 75^{\text {LNGFR }}$ may act as a common binding molecule for all neurotrophins. The function of the $p$ 75 $5^{\text {LNGFR }}$ in mediating the biological effects of neurotrophins is still not clear.

The dependence of neurons on neurotrophic factors is developmentally regulated. Developing sympathetic and sensory neurons require NGF for survival while the requirement for NGF by these neurons declines with maturity (Coughlin et al., 1977; Thoenen and Barde, 1980; Johnson et al., 1986; Ruit et al., 1990). Similarly, the dependence of motoneurons for survival on their target, which presumably provides the neurotrophic factors for motoneurons, is diminished when animals mature (Crews and Wigston, 1990; Snider et al., 1992). Although BDNF promotes the survival of immature motoneurons, it remains to be determined whether it can influence the function of adult motoneurons. The demonstration of a survival-promoting effect of BDNF on developing motoneurons suggests its potential use in the treatment of amyotrophic lateral sclerosis (ALS), a degenerative motoneuron disease (Williams and Windebank, 1991). However, since ALS is a late-onset disease, it is important to determine if BDNF can affect adult motoneurons in an animal model. In the present study, we showed that adult motoneurons express $t r k B$ receptor $m R N A$ and protein. In addition to possessing BDNF receptors, we demonstrated that adult motoneurons are capable of responding to exogenous BDNF in a dose-dependent manner. We also compared the differences in the efficacy of BDNF administered by different routes.

\section{Materials and Methods}

Materials. Recombinant human BDNF was produced in Escherichia coli transfected with a BDNF expression vector and purified by the protein chemistry group at Amgen. The biological activities of BDNF were routinely assessed using a chicken DRG explant assay (Lindsay et al., 1985). Mouse anti-rat low-affinity NGF receptor, p75 ${ }^{\text {LNGFR }}$ antibody (192-IgG) was a gift from Dr. Eugene M. Johnson. Affinity-purified rabbit anti-rat $t r k \mathrm{~B}$ peptide (amino acid sequence 23-36, Middlemas et al., 1991) polyclonal antibody was a gift from Drs. Stuart Feinstein and Monte Radeke. Mouse monoclonal antibody against choline acetyltransferase was purchased from Chemicon (Temecula, CA). Biotinylated affinity-purified horse anti-mouse antibodies, goat anti-rabbit antibodies, and ABC kits were bought from Vector Laboratories (Burlingame, CA). ${ }^{33}$ P-UTP was purchased from Du Pont/New England Nuclear (Boston, MA). Reagents for the synthesis of riboprobes were obtained from Promega (Madison, WI). Sprague-Dawley rats were purchased from Charles River Laboratories (Wilmington, MA). All other reagents, unless specified, were obtained from Sigma (St. Louis, MO).

In situ hybridization and immunohistochemical studies of $\operatorname{trk} B m R N A$ and protein in adult rat spinal cord. Adult Sprague-Dawley rats were perfused transcardially with phosphate-buffered saline (PBS) followed by $4 \%$ paraformaldehyde in $0.1 \mathrm{~m}$ phosphate buffer ( $\mathrm{pH} \mathrm{7.2)}$ ). The brains and cervical spinal cords were removed, postfixed in the same fixative for $2 \mathrm{hr}$ at $4^{\circ} \mathrm{C}$, and cryoprotected in $30 \%$ sucrose in PBS overnight at $4^{\circ} \mathrm{C}$.

${ }^{33} \mathrm{P}$-UTP-labeled antisense and sense riboprobes corresponding to the extracellular domain of rat $t r k \mathrm{~B}$ receptors were made with the Promega Riboprobe Kit. The $t r k$ receptor constructs were gifts from Dr. Jeff Milbrandt and have been described previously (Carroll et al., 1992).

For in situ hybridization, brains and spinal cords were cut into $8 \mu \mathrm{m}$ coronal sections with a cryostat microtome and stored at $-20^{\circ} \mathrm{C}$ until use. The in situ hybridization was carried out as previously described (Carroll et al., 1992).

For trkB immunohistochemistry, brainstems and cervical spinal cords were cut into $80 \mu \mathrm{m}$ serial sections. Sections were then processed for immunohistochemistry using affinity-purified rabbit anti-trkB (trkB2336) or normal rabbit IgG as control at $2 \mu \mathrm{g} / \mathrm{ml}$ and followed by $2 \mu \mathrm{g} /$ $\mathrm{ml}$ secondary biotinylated goat anti-rabbit and the ABC method as described previously (Yan and Johnson, 1988).
Animal surgery and BDNF treatments. Adult rats were anesthetized with a cocktail $(43 \mathrm{mg} / \mathrm{ml}$ of ketamine hydrochloride, $8.6 \mathrm{mg} / \mathrm{ml}$ of xylazine, and $1.43 \mathrm{mg} / \mathrm{ml}$ of acepromazine) at a dose of $0.7 \mathrm{ml} / \mathrm{kg}$ body weight. The right facial nerve was transected near the stylo-mastoid foramen. For local administration, a $5 \times 5 \times 3 \mathrm{~mm}^{3}$ piece of Gelfoam soaked in $2.8 \mathrm{mg} / \mathrm{ml}$ of BDNF in PBS ( $n=10$ for ChAT activity assay and $n=7$ for immunohistochemistry) or PBS alone ( $n=10$ for ChAT activity assay and $n=7$ for immunohistochemistry) was implanted into the cut site at the time of surgery. For subcutaneous treatment, BDNF in PBS at the doses of $0,2,5,10$, and $20 \mathrm{mg} / \mathrm{kg}$ body weight were subcutaneously injected daily behind the neck of rats $(n=4$ for each dose). For intravenous administration, animals were cannulated through the jugular vein with PE 50 tubing at the time of facial nerve lesion and were treated daily with BDNF in PBS at concentrations of $0,2,5,10$, and $20 \mathrm{mg} / \mathrm{kg}$ body weight ( $n=4$ for each dose). For the intracerebral ventricular administration study, a catheter was stereotaxically implanted into the right lateral ventricle of the brain $(0.9 \mathrm{~mm}$ posterior to the bregma, $1.5 \mathrm{~mm}$ lateral to the midline, and $4.0 \mathrm{~mm}$ from the surface of the skull) (Paxinos and Watson, 1986) at the time of facial nerve lesion. The catheter was attached to a miniosmotic pump with an infusion rate of $0.1 \mu \mathrm{l} / \mathrm{hr}$ (model 2002) (Alzet, Palo Alto, CA). The miniosmotic pumps were filled with BDNF in PBS at the concentrations of $0,0.2,1$, and $5 \mathrm{mg} / \mathrm{ml}(n=4$ for each dose). The miniosmotic pump was implanted subcutaneously according to manufacturer's instructions. Animals from all experiments were killed $7 \mathrm{~d}$ after the facial nerve transection.

ChAT activity assay. The effect of BDNF on the ChAT activity of lesioned adult facial motoneurons was assessed in rats receiving local BDNF treatment. Rats were killed by $\mathrm{CO}_{2}$ inhalation, and their brains were removed. A $1.7-\mathrm{mm}$-thick slice of the brainstem containing the facial nucleus was cut out with a tissue chopper according to a brain atlas (Paxinos and Watson, 1986) and ipsilateral and contralateral nuclei were dissected out. Tissues were sonicated and then centrifuged at 16,000 $\times g$ for $10 \mathrm{~min}$ at $4^{\circ} \mathrm{C}$. The supernatants were collected and the protein contents of individual samples were determined by the Pierce protein assay (Pierce, Rockford, IL). Samples were normalized for protein content and assayed for ChAT activity in triplicate according to the published protocol (Fonnum, 1975). Since the ChAT activities of nonlcsioned nuclei of both PBS $(47.13 \pm 4.64, \mathrm{pmol} / \mathrm{min} / \mathrm{mg}$ protein) and $\operatorname{BDNF}(45.72 \pm 4.43, \mathrm{pmol} / \mathrm{min} / \mathrm{mg}$ protein $)$ treatments were the same, the results were expressed as a ratio of lesioned over control facial nuclei. Data were analyzed statistically with a two-tailed Student's $t$ test.

ChAT and 192-IgG immunohistochemistry. Rats were killed by an overdose of anesthesia and perfused transcardially with PBS followed by $4 \%$ paraformaldehyde in $0.1 \mathrm{~m}$ sodium phosphate buffer, $\mathrm{pH} 7.2$. The brainstems were removed, cryoprotected with $30 \%$ sucrose in PBS, and frozen onto a sliding microtome chuck, and $80 \mu \mathrm{m}$ serial coronal sections were cut through the facial nucleus region and collected into four sets (three to five sections per set). Sections were then processed for immunohistochemistry with either mouse monoclonal antibody against ChAT (ascites, 1:500), mouse monoclonal antibody (192-IgG) against $\mathrm{p} 75^{\mathrm{LNGFR}}(2 \mu \mathrm{g} / \mathrm{ml})$, or a non-sense mouse myeloma IgG followed by $2 \mu \mathrm{g} / \mathrm{ml}$ of secondary biotinylated horse anti-mouse and the $A B C$ method (Yan and Johnson, 1988).

Quantification of immunohistochemical sections. A Quantimet 520 image analyzer (Leica, Inc., Deerfield, IL) coupled to a Nikon OptiphotFXA microscope was used to quantify the relative intensity of ChAT and 192-IgG staining. A $510 \mathrm{~nm}$ narrow-band pass filter (Oriel Corp., Stratford, CT) was used with a Nikon-Plan Apochromatic $2 \times$ objective lens to produce high-contrast images of the facial nucleus region in histology sections. The relative intensity of ChAT immunoreactivity was determined by obtaining the mean gray scale intensity for each outlined nucleus minus the background staining of adjacent ChAT negative gray matter. The relative intensity of $192-\mathrm{IgG}$ staining was determined by obtaining the mean gray scale intensity for each outlined nucleus without the subtraction of the adjacent non-facial-nuclcus gray matter, since the nonlesioned facial nucleus was $192-\mathrm{IgG}$ negative and had the same optical intensity as that of adjacent gray matter. Between two and five sections of the facial nucleus per animal (average of 3.2 sections per animal) were used for the quantification. Since BDNF treatments via local, systemic, and intracerebroventricular routes did not affect the ChAT and 192-IgG immunostaining of the nonlesioned facial nucleus, the data were expressed as the ratio of the relative optical density of lesioned over nonlesioned facial nuclei of same sections. The data were statistically analyzed by ANOVA followed by the Dunnett $t$ test for a given route of administration or by a two-tailed Student's $t$ 

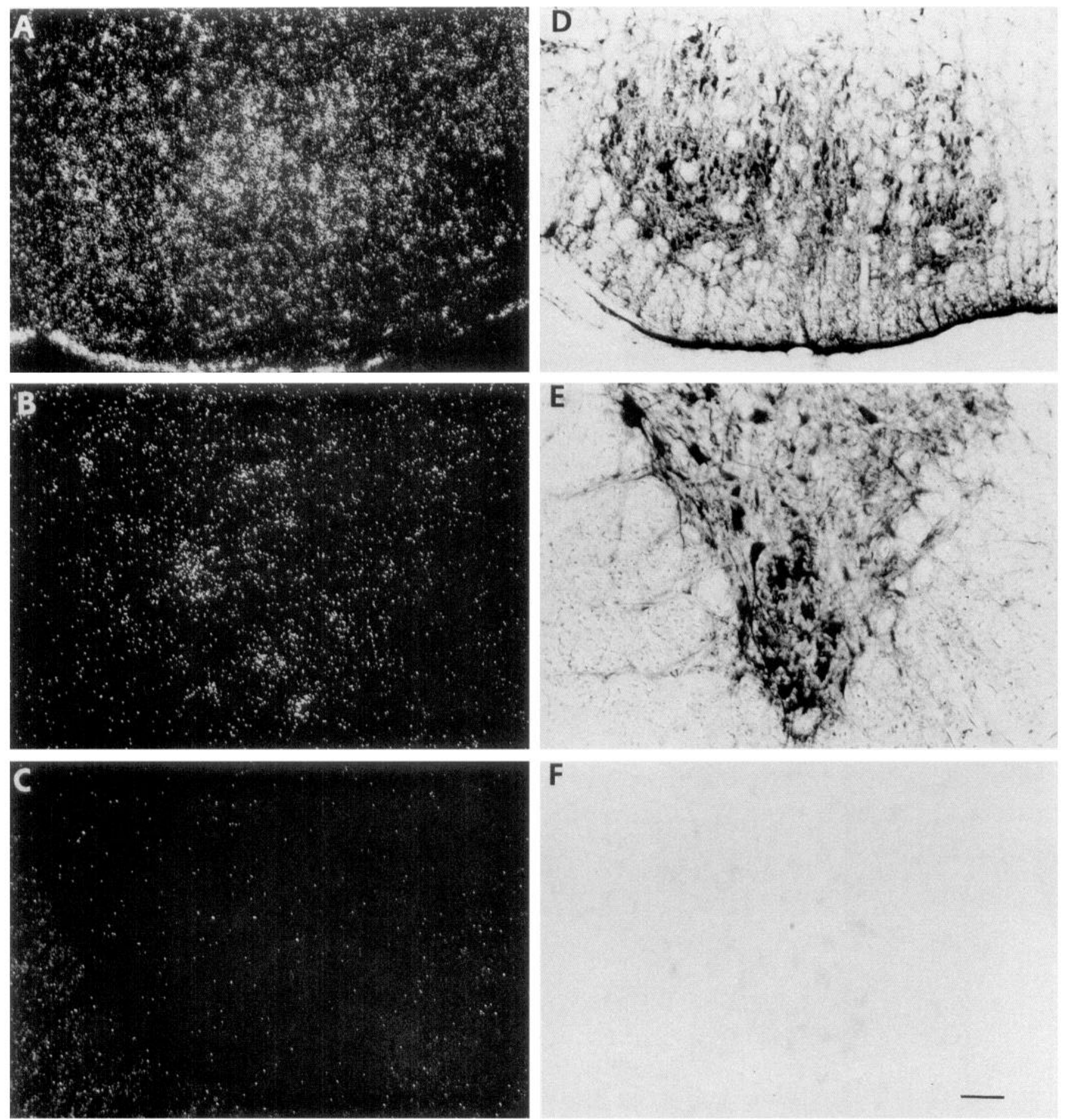

Figure 1. Expression of $t r k \mathrm{~B}$ in adult motoneurons. The expression of $t r k \mathrm{~B}$ by motoneurons was studied by in situ hybridization $(A-C$, dark-field photographs) and immunohistochemical $(D-F$, bright-field photographs) techniques. Motoneurons in the facial nucleus $(A)$ and spinal cord $(B)$ were positively labeled by an antisense riboprobe to trkB. There was no labeling of motoneurons by a corresponding sense riboprobe $(C)$. Motoneurons in the facial nucleus $(D)$ and spinal cord $(E)$ were also positively stained by affinity-purified rabbit anti-rat $t r k B$ polyclonal antibodies. The staining was localized to the motoneuron soma and processes. Replacement of the primary antibodies with a control rabbit IgG resulted in no staining of the motoneurons of the spinal cord $(F)$. Scale bar (in $F$ ): $150 \mu \mathrm{m}$ for $A$ and $D, 375 \mu \mathrm{m}$ for $B, C, E$, and $F$.

test for the same dose of BDNF by different route of administration (subcutaneous vs intravenous).

\section{Results}

Adult motoneurons express $B D N F$ receptor, $\operatorname{trk} B$

Developing and adult spinal motoneurons have been shown to express trkB mRNA (Ernfors et al., 1992; Merlio et al., 1992;
Yan et al., 1993). In an extension of these findings, high levels of $t r k \mathrm{~B}$ mRNA were detected in other populations of adult motoneurons including facial (Fig. $1 \mathrm{~A}$ ) and hypoglossal motoneurons (not shown). Comparable high levels of expression were seen in adult spinal cord motoneurons (Fig. $1 B$ ). Consistent with these in situ hybridization results, facial and spinal motoneurons of adult rats were positively stained with affinity-purified rabbit 
A
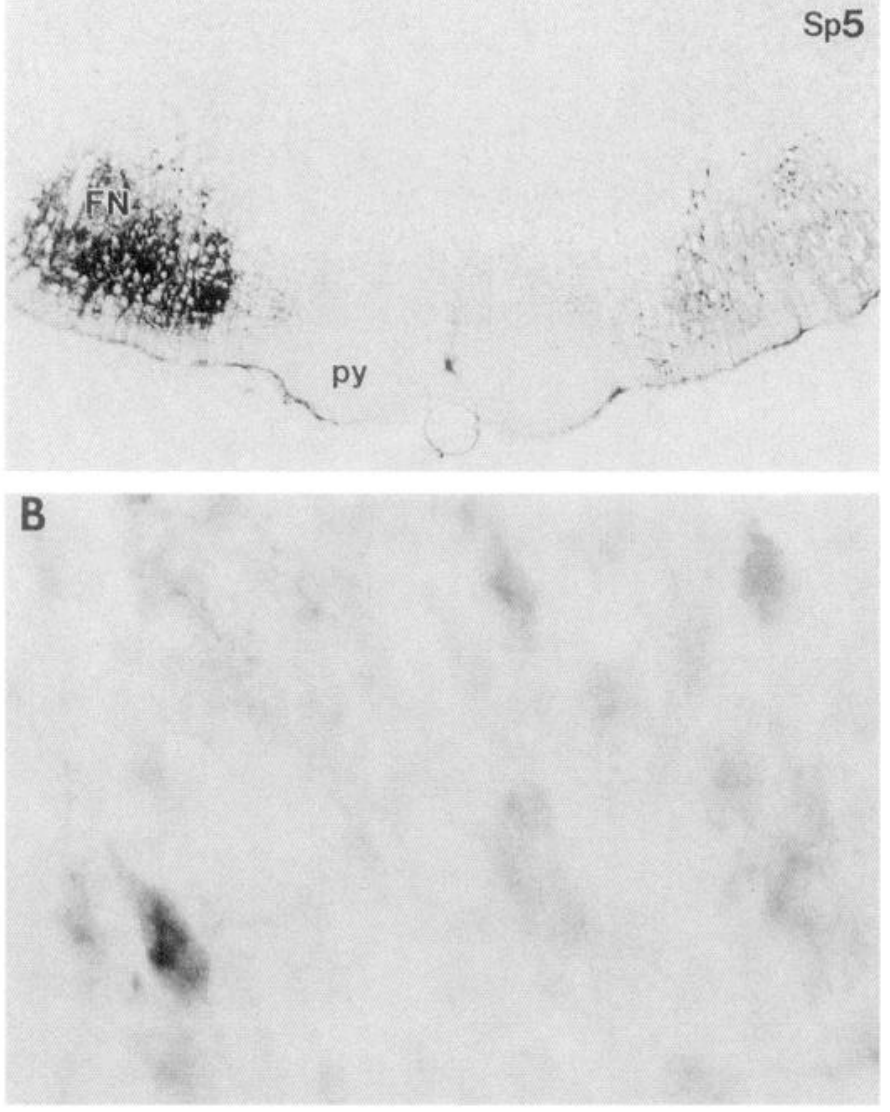

C

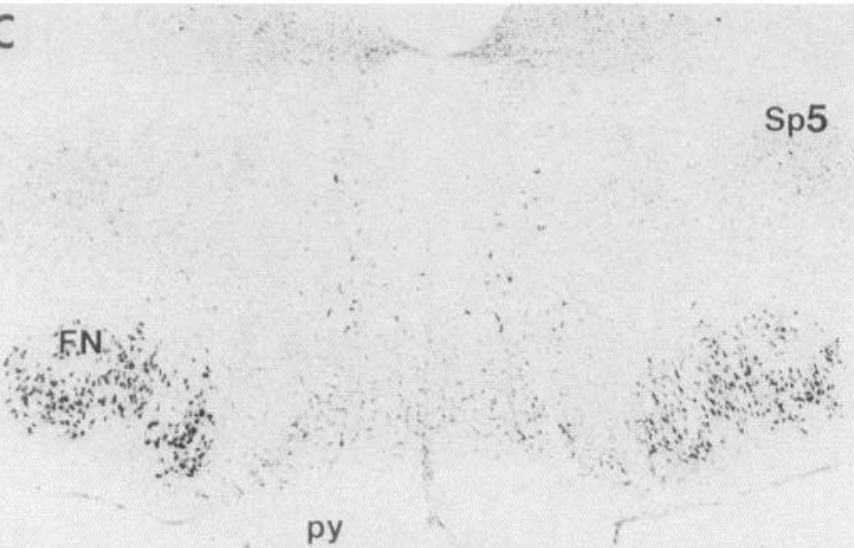

D
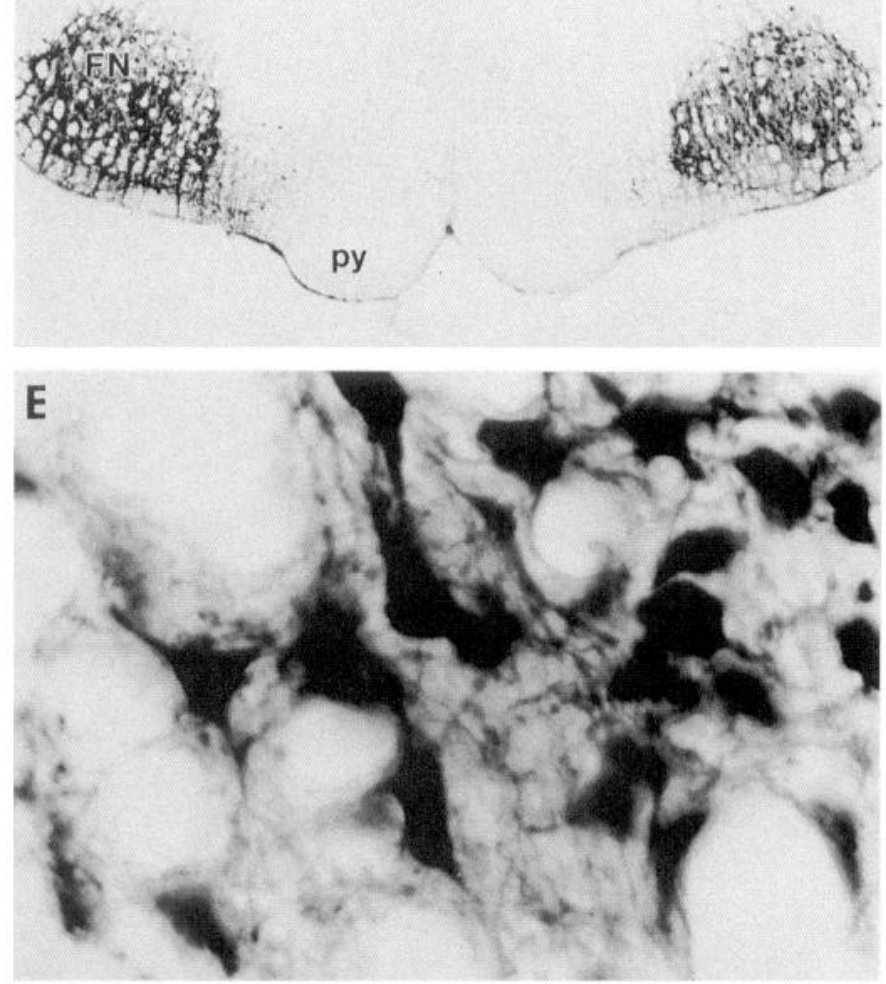

$\mathbf{F}$

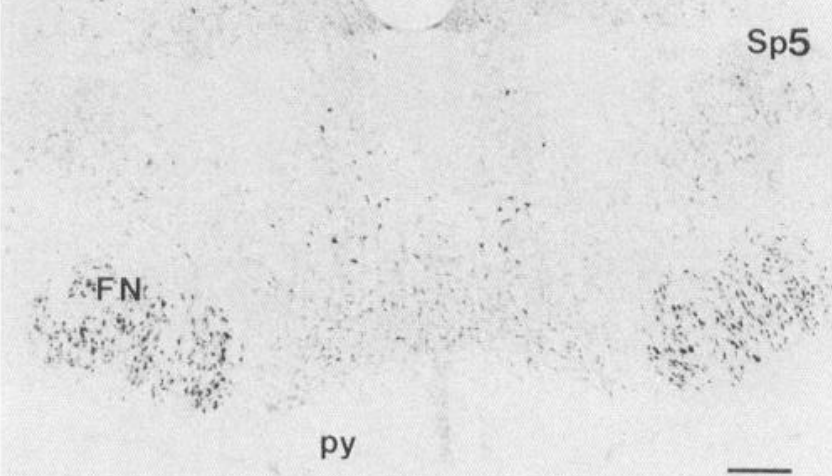

Figure 2. ChAT immunohistochemistry and Nissl staining of axotomized facial motoneurons. The right facial nerve was transected and animals were locally treated with either PBS $(A-C)$ or $\operatorname{BDNF}(D-F)$ for $7 \mathrm{~d}$. In the PBS-treated rats, axotomy resulted in a large drop in ChAT immunoreactivity in the lesioned facial nucleus $(A)$. BDNF treatment largely attenuated the lesion-induced drop of ChAT immunoreactivity $(D)$. The staining on individual motoneurons after the BDNF treatment $(E)$ was much higher than those receiving PBS treatment $(B)$. Nissl staining of adjacent sections of either PBS- $(C)$ or BDNF- $(F)$ treated rats indicated that the change in ChAT immunoreactivity was not due to the loss of neuronal cell bodies after axotomy. $F N$, facial nucleus; $p y$, pyramidal tract; $S p 5$, nucleus of spinal tract of trigeminal. Scale bar (in $F$ ): $500 \mu \mathrm{m}$ for $A, C, D$, and $F ; 50$ $\mu \mathrm{m}$ for $B$ and $E$.

polyclonal anti-trkB peptide antibodies (Fig. 1D,E). Staining was localized to motoneuron soma as well as dendrites. In addition to the motoneurons, there were many other cells expressing $t r k \mathrm{~B}$ in the brainstem and the spinal cord of adult rats. However, motoneurons were among the highest trkB mRNAexpressing and immunoreactive cells in the adult CNS.
Effects of locally administered BDNF on axotomized facial motoneurons

Axotomy in adult rats causes a rapid and reproducible decrease of ChAT immunoreactivity in motoneurons (Lams et al., 1988; Armstrong et al., 1991). In addition, axotomy induces the re- 


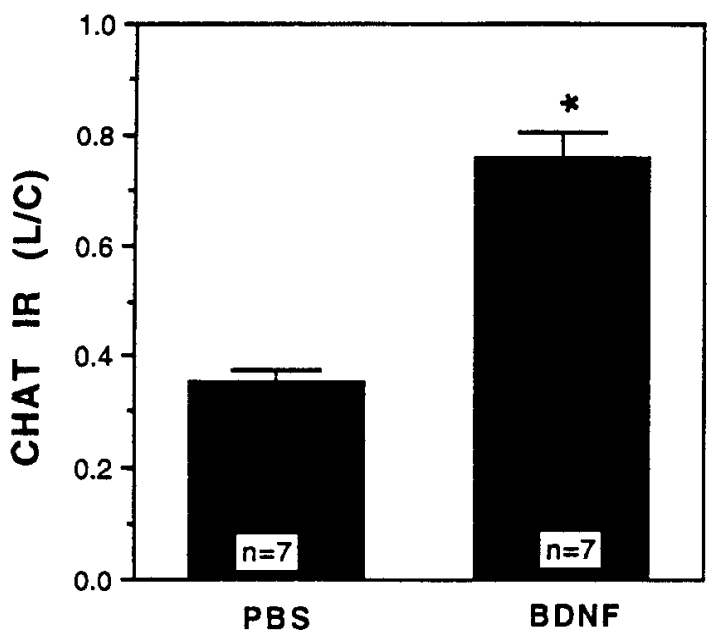

TREATMENT

Figure 3. Quantification of ChAT immunoreactivity of the facial nucleus after local administration of PBS or BDNF for $7 \mathrm{~d}$. Values are means $\pm \operatorname{SEM}(n=7)$. BDNF significantly attenuated the axotomyinduced decrease of ChAT immunoreactivity in the lesioned facial nucleus $\left(^{*}, p<0.0001\right.$, two-tailed Student $t$ test $)$.

expression of $\mathrm{p} 75^{\mathrm{LNGFR}}$ in adult motoneurons (Ernfors et al., 1989; Wood et al., 1990; Armstrong et al., 1991; Koliatsos et al., 1991), which is normally expressed only transiently by developing motoneurons (Yan and Johnson, 1988). To evaluate the effects of BDNF on adult motoneurons, we used a facial nerve transection paradigm to study its influence on the expression of ChAT and $\mathrm{p} 75^{\mathrm{LNGFR}}$.

Seven days after right facial nerve transection, ChAT immunoreactivity largely disappeared from the lesioned facial nucleus receiving PBS treatment (Fig. $2 A$ ). Staining on a few remaining ChAT-positive facial motoneurons was quite diffuse (Fig. 2B). BDNF locally applied in a Gelfoam implant to the proximal stump of the cut facial nerve largely attenuated the lesion-induced decrease of ChAT immunoreactivity (Fig. 2D). The ChAT immunoreactivity on individual axotomized motoneurons after BDNF treatment (Fig. 2E) was much higher than those receiving PBS treatment (Fig. $2 B$ ) and approached the level of contralateral, nonlesioned motoneurons. Nissl staining of adjacent sections revealed that the disappearance of ChA Tpositive cells in the lesioned facial nucleus was not due to the loss of neurons (Fig. 2C,F, PBS and BDNF treated, respectively), confirming previous reports (Lams et al., 1988; Armstrong et al., 1991).

To quantify this phenomenon, the average optical densities of both lesioned and nonlesioned facial nuclei of ChAT-immunostained sections were measured. Since locally applied BDNF did not influence the ChAT immunoreactivity of nonlesioned motoneurons (Fig. 2D), the result was expressed as the ratio of the gray scale value of lesion over control. Only $35 \%$ of the ChAT immunoreactivity remained in lesioned facial nuclei in PBS-treated animals. Locally applied BDNF resulted in the retention of $76 \%$ of the ChAT immunoreactivity in the lesioned facial nucleus, a twofold improvement compared to PBS-treated controls (Fig. 3).

To verify the protective effect of BDNF on ChAT immunoreactivity of lesioned motoneurons, the ChAT activities of dissected lesioned and nonlesioned facial nuclei from animals treated with locally applied PBS or BDNF were measured. The lesion

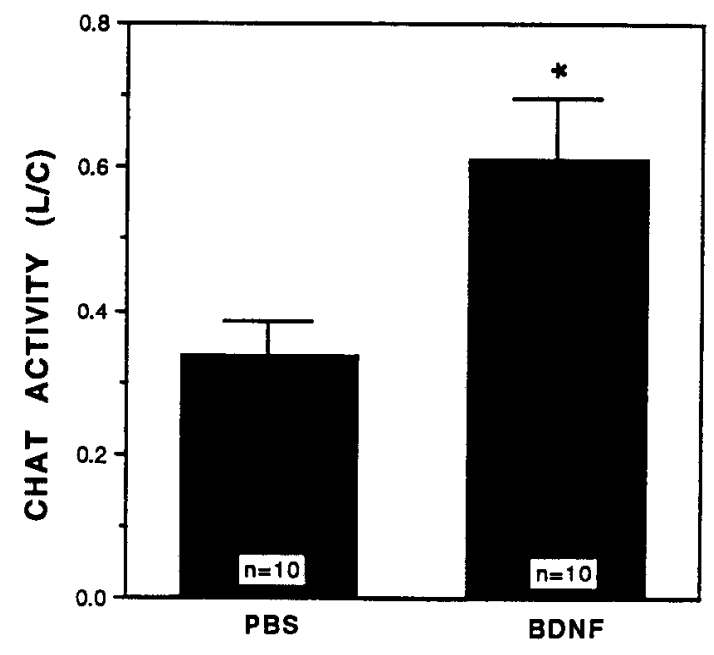

TREATMENT

Figure 4. Effect of locally administered BDNF (7 d) on ChAT activity of axotomized facial nucleus. Values are means $\pm \operatorname{SEM}(n=10)$. BDNF significantly attenuated the axotomy-induced decrease of ChAT activity in the lesioned facial nucleus $\left(^{*}, p<0.0001\right.$, two-tailed Student $t$ test).

caused a large decrease of ChAT activity (34\% of nonlesion) and BDNF treatment could attenuate this decrease $(62 \%$ of nonlesion) in the facial nucleus (Fig. 4). As found in our ChAT immunohistochemistry studies, BDNF treatment markedly attenuated the decrease of ChAT activity but did not stimulate its level over that of nonlesioned motoneurons.

In the adult facial nucleus, axotomy induced an upregulation of p75 ${ }^{\text {LNGFR }}$ immunoreactivity from a nondetectable to a detectable level (Fig. 5A). BDNF locally applied to the proximal stump of the cut facial nerve for $7 \mathrm{~d}$ further potentiated the lesion-induced reexpression of $\mathrm{p} 75^{\mathrm{LNGFR}}$ immunoreactivity (Fig. $5 B$ ). The quantification of $\mathrm{p} 75^{\mathrm{LNGFR}}$ immunoreactivity by measuring the average optical densities of facial nuclei is shown in Figure 6. Lesion plus PBS treatment resulted in a slight increase of p75 LNGFR immunoreactivity (119\% of nonlesion, not statistically significant) and BDNF treatment significantly augmented this reexpression of $p 75^{\text {LNGFR }}$ immunoreactivity ( $207 \%$ of nonlesion).

\section{Comparison of the effectiveness of different routes of $B D N F$ administration}

The results presented above demonstrate a significant effect of BDNF when administered locally at the site of axotomy on adult motoneurons. We next determined whether systemic or intracerebroventricular administration of BDNF could influence axotomized motoneurons in a dose-dependent fashion. Since ChAT activity measurements were less sensitive and more variable than the measurements of the average optical densities of ChAT immunoreactivity of stained sections, the latter method was used to quantify the effects of axotomy and BDNF treatment. The ChAT immunoreactivities of the left, nonlesioned facial nuclei of animals treated with PBS or BDNF at different doses and via different routes did not differ significantly (relative optical densities of PBS treatment vs BDNF treatments of all doses pooled: 99.0 vs 95.6 for subcutaneous; 100.3 vs 101.7 for intravenous, and 97.0 vs 94.2 for intracerebroventricular). The left facial nucleus was thercfore used as a internal control, and the data were expressed as the ratio of lesion over control. 


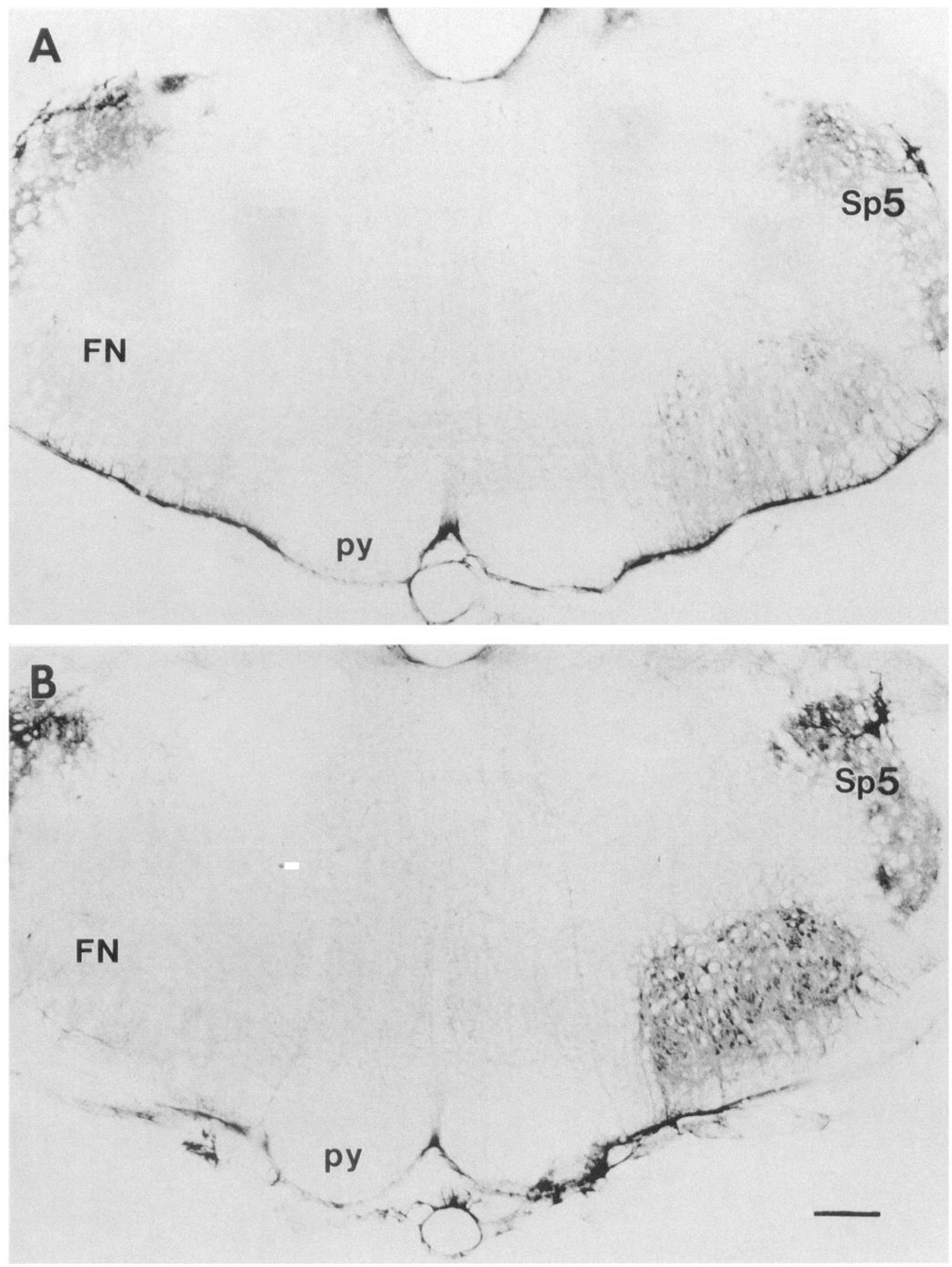




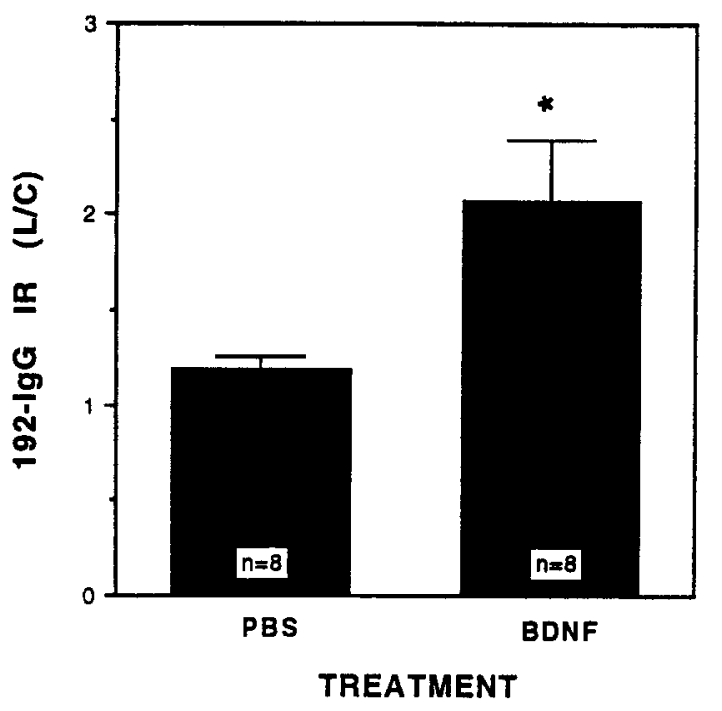

Figure 6. Quantification of $192-\mathrm{IgG}$ immunoreactivity of the facial nucleus in rats that received local administered PBS or BDNF for $7 \mathrm{~d}$. Values are means $\pm \operatorname{SEM}(n=8)$. BDNF significantly enhanced the axotomy-induced increase of 192-IgG immunoreactivity in the lesioned facial nucleus $\left(^{*}, p<0.016\right.$, two-tailed Student $t$ test $)$.

The results of daily systemic administration for $7 \mathrm{~d}$ by either subcutaneous or intravenous routes along with intracerebroventricular infusion of BDNF for $7 \mathrm{~d}$ on ChAT immunoreactivity of axotomized facial nuclei are summarized in Figure 7. Both subcutaneously and intravenously administered BDNF reduced the lesion-induced decrease of ChAT immunoreactivity (Fig. 7A) in a dose-dependent fashion. At a dose of $2 \mathrm{mg} / \mathrm{kg}$ body weight, intravenously administered BDNF was significantly better than subcutaneously administered BDNF in attenuating the lesion-induced decrease of ChAT immunoreactivity ( $p<0.001$, two-tailed Student $t$ test). At higher doses, these two routes of systemic administration resulted in similar ChAT staining levels and reached the efficacy of locally applied BDNF (Fig. 3). BDNF infused intracerebroventricularly also attenuated the lesion-induced decrease of ChAT immunoreactivity in the facial nucleus in a dose-dependent fashion. Much lower daily doses of BDNF administered by intracerebroventricular infusion were needed versus systemic administration. The maximum protective effect of BDNF by intracerebroventricular administration was achieved at a dose of $60 \mu \mathrm{g} / \mathrm{d}$ (Fig. $7 B$ ) and was similar to the results of locally applied BDNF (Fig. 3) and systemically applied BDNF at the high doses (Fig. $7 A$ ).

\section{Effect of BDNF on animal weight gain after different routes of administration}

The potential side effects of BDNF treatment on animals by different routes of administration were evaluated by monitoring animals' weight gain during these experiments (Table 1). Animals receiving BDNF subcutaneous treatment at all the dosages did not show significantly different weight gain compared to
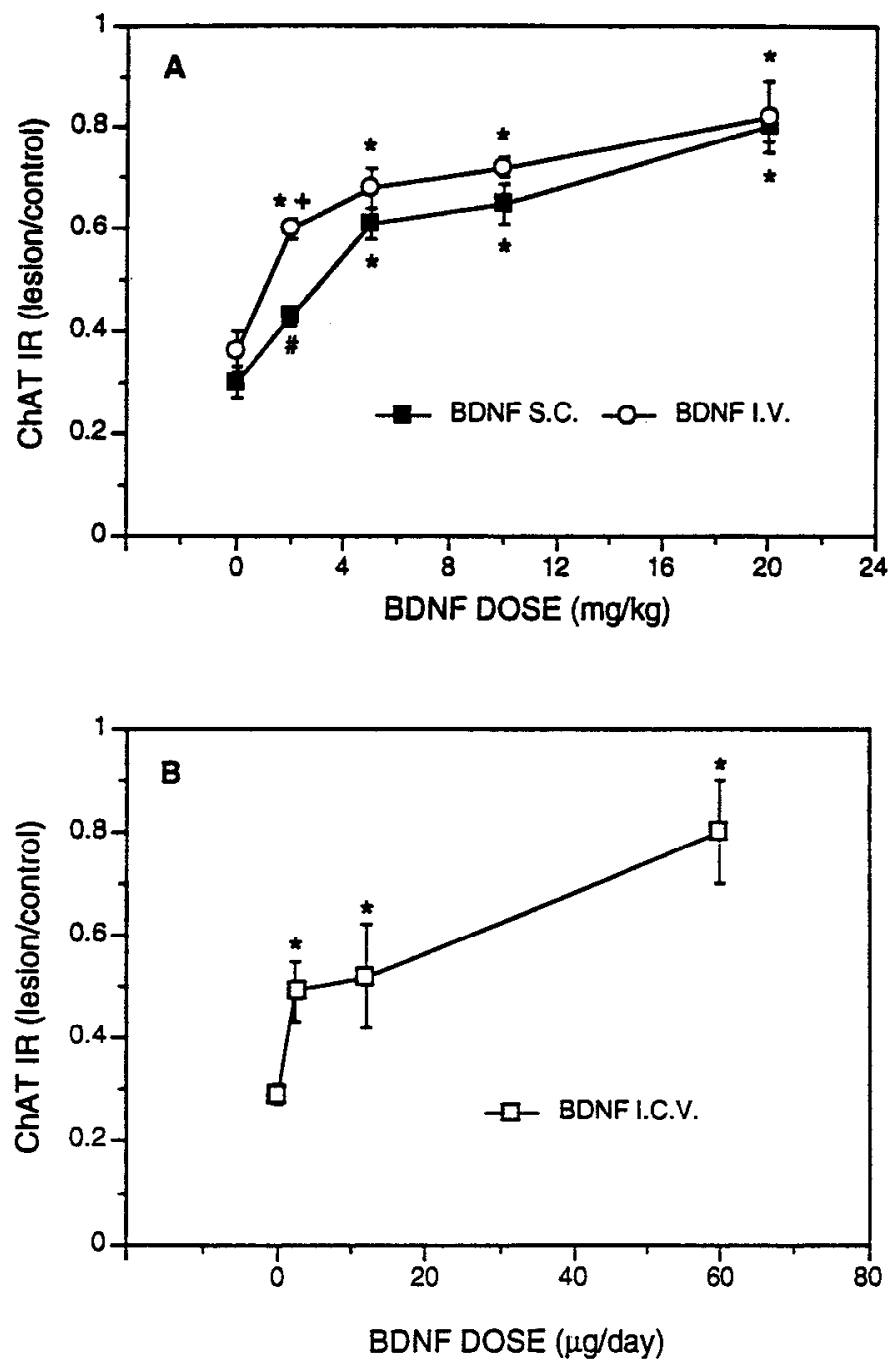

Figure 7. Dose-response curve of systemicly $(A)$ or intracerebroventricularly $(B)$ administered BDNF on ChAT immunoreactivity of the lesioned facial nucleus. $A$, Animals received daily injections of BDNF either subcutaneously $(S . C ., \square)$ or intravenously $(I . V ., O)$ at the doses indicated for $7 \mathrm{~d}$. Systemically administered BDNF by both routes resulted in attenuation of the lesion-induced decrease of ChAT immunoreactivity in a dose-dependent fashion. Values are means \pm SEM $(n=4)$. Data were analyzed by ANOVA followed by Dunnett $t$ test $\left(^{*}\right.$, $p<0.01 ; \#, p<0.05$, BDNF vs control). At the dose of $2 \mathrm{mg} / \mathrm{kg}$, BDNF administered intravenously was more effective than BDNF administered subcutaneously $(+, p<0.001$, two-tailed Student $t$ test). There were no significant differences in ChAT immunoreactivity at higher doses of BDNF when we compared these two different routes of administration. $B$, Animals received BDNF continuously infused into the lateral ventricle (I.C.V.) through miniosmotic pumps at the doses indicated for $7 \mathrm{~d}$. BDNF administered intracerebroventricularly resulted in attenuation of the lesion-induced decrease of ChAT immunoreactivity in a dose-dependent fashion. Values are means \pm SEM $(n=4)$. Data were analyzed by ANOVA followed by Dunnett $t$ test $\left(^{*}, p<0.01\right.$, BDNF vs control).

Figure 5. 192-IgG immunohistochemistry of the axotomized facial motoneurons. The right facial nerve was transected and animals were locally treated with either PBS $(A)$ or BDNF $(B)$ for $7 \mathrm{~d}$. In the PBS-treated rats, axotomy resulted in a detectable increase of $192-$ IgG staining in the lesioned facial nucleus. The treatment of BDNF augmented the lesion-induced upregulation of 192-IgG immunoreactivity. There was no detectable staining in the left, nonlesioned facial nucleus. $192-\mathrm{IgG}$ also stained the nucleus of spinal tract of trigeminal (Sp5), which is known to be p75 7 LAFR positive (Yan and Johnson, 1988). $F N$, facial nucleus; $p y$, pyramidal tract; $S p 5$, nucleus of spinal tract of trigeminal. Scale bar, $500 \mu$ m. 


\begin{tabular}{lcllr}
\hline \multicolumn{5}{l}{ Table 1. The effect of different routes of BDNF administration on animal body weight } \\
Route & Dose & $\begin{array}{l}\text { Day 0 } \\
\text { (mean, gm) }\end{array}$ & $\begin{array}{l}\text { Day } 7 \\
\text { (mean, gm) }\end{array}$ & \% gain (or loss) \\
\hline s.c. & 0.0 & $200.75 \pm 7.11$ & $218.75 \pm 10.29$ & $8.88 \pm 1.97$ \\
$(\mathrm{mg} / \mathrm{kg})$ & 2.0 & $200.25 \pm 6.30$ & $213.50 \pm 7.50$ & $6.61 \pm 1.49$ \\
& 5.0 & $210.00 \pm 3.56$ & $221.25 \pm 3.07$ & $5.38 \pm 0.91$ \\
& 10.0 & $192.25 \pm 1.38$ & $204.50 \pm 3.84$ & $6.35 \pm 1.29$ \\
& 20.0 & $217.25 \pm 8.39$ & $228.75 \pm 6.61$ & $5.41 \pm 1.06$ \\
i.v. & 0.0 & $197.67 \pm 2.03$ & $216.00 \pm 2.31$ & $9.27 \pm 0.10$ \\
$(\mathrm{mg} / \mathrm{kg})$ & 2.0 & $194.00 \pm 3.37$ & $207.50 \pm 6.06$ & $6.92 \pm 1.99$ \\
& 5.0 & $208.50 \pm 8.70$ & $216.25 \pm 9.42$ & $3.94 \pm 4.05$ \\
& 10.0 & $201.00 \pm 5.34$ & $204.00 \pm 5.80$ & $1.48 \pm 0.44$ \\
& 20.0 & $207.50 \pm 7.03$ & $195.50 \pm 14.79$ & $(-5.69 \pm 6.65)^{*}$ \\
i.c.v. & 0.0 & $264.25 \pm 7.50$ & $270.00 \pm 6.10$ & $2.23 \pm 0.80$ \\
$(\mu \mathrm{g} /$ day) & 2.4 & $284.50 \pm 9.00$ & $254.75 \pm 11.37$ & $(-10.35 \pm 3.73)^{* *}$ \\
& 12.0 & $251.00 \pm 10.35$ & $207.25 \pm 8.44$ & $(-17.37 \pm 1.56)^{* *}$ \\
& 60.0 & $268.00 \pm 10.66$ & $216.00 \pm 14.91$ & $(-19.52 \pm 3.88)^{* *}$
\end{tabular}

Body weights of each individual rat ( $n=4$ for all groups) were mcasurcd daily, beginning on day 0 (prior to surgery) and ending on day 7 (prior to perfusion); only those weights of day 0 and of day 7 are shown. ${ }^{*}, p<0.05 ;{ }^{* *}, p<0.01$ compared with the corresponding values of vehicle treated animals (one-way ANOVA followed by Dunnett $t$ test).

animals receiving $\mathrm{PBS}$ treatment. In contrast, animals receiving BDNF intravenously showed a dose-dependent reduction in weight gain. At $5 \mathrm{mg} / \mathrm{kg}$ and $10 \mathrm{mg} / \mathrm{kg}$, animals showed a tendency to gain less weight (not statistically significant due to the small number of animals used) while those receiving $20 \mathrm{mg} / \mathrm{kg}$ significantly lost weight $(p<0.05)$. Animals receiving BDNF intracerebroventricular treatment at all doses had a significant weight loss in a dose-dependent fashion.

\section{Discussion}

In an extension of our previous finding that BDNF functions as a survival-promoting factor for developing motoneurons (Oppenheim et al., 1992; Yan et al., 1992), we found in this study that adult motoneurons remain biologically responsive to BDNF. Specifically, BDNF treatment attenuated the decrease of ChAT immunoreactivity and activity in adult facial motoneurons induced by axotomy. Furthermore, we found that exogenous BDNF augmented the lesion-induced reexpression of $\mathrm{p} 75^{\text {LNGFR }}$ in adult facial motoneurons.

We have shown here that adult brainstem and spinal motoneurons express trkB mRNA and protein. These findings are in agreement with those of previous $\operatorname{rk} \mathrm{B}$ in situ hybridization results (Ernfors et al., 1992; Merlio et al., 1992; Yan et al., 1993). Spinal motoneurons express $\operatorname{rk} \mathrm{B}$ mRNA as early as E13 and continue into adulthood (Yan et al., 1993). This continued expression of the BDNF receptor by motoneurons suggests a capacity to respond to BDNF from early development through to adulthood. The $t r k \mathrm{~B}$ gene encodes at least three cell surface receptors, including a full-length form and two truncated forms (Klein et al., 1990; Middlemas et al., 1991). The full-length form with the intracellular tyrosine kinase catalytic domain apparently mediates the biological activity of BDNF. In the present study, a riboprobe corresponding to the extracellular domain of $t r k \mathrm{~B}$ was used for in situ hybridization. The antibody used in the immunohistochemistry was also directed against trkB extracellular domain and would detect both truncated and fulllength $t r k \mathrm{~B}$ receptors. Thus, it could not be determined whether motoneurons express only one form or both full-length and truncated forms. The demonstration of $t r k \mathrm{~B}$ immunoreactivity is consistent with the fact that motoneurons are capable of retrogradely transporting BDNF in a receptor-mediated fashion (DiStefano et al., 1992; Yan et al., 1992, 1993). The presence of $t r k \mathrm{~B}$ protein on motoneuron dendrites suggests that motoneurons may receive BDNF from within the brainstem or spinal cord in addition to their muscle target (Henderson et al., 1993; Koliatsos et al., 1993) and Schwann cells (Acheson et al., 1991; Meyer et al., 1992). Since the level of BDNF mRNA present in the adult spinal cord and brainstem is relatively low (Maisonpierre et al., 1990), the major CNS source of BDNF for motoneurons may be derived from the monosynaptic afferent fibers of a subset of sensory neurons that express high levels of BDNF mRNA (Ernfors and Persson, 1991; Schecterson and Bothwell, 1992).

The dependence of motoneurons on their targets and neurotrophic factors decreases as animals mature. Unlike neonatal rats (Schmalbruch, 1984; Snider et al., 1992; Yan et al., 1992), axotomy of motor nerves in the adult does not cause motoneuron cell death (Lams et al., 1988). In order to determine whether BDNF can influence adult motoneurons, we examined whether BDNF could prevent the axotomy-induced decrease of ChAT immunoreactivity and activity (Lams et al., 1988; Armstrong et al., 1991), and prevent the axotomy-induced increase of p75 ${ }^{\text {LNGFr }}$ immunoreactivity (Ernfors et al., 1989; Wood et al., 1990; Koliatsos et al., 1991) in facial motoneurons. We found that exogenous BDNF could markedly attenuate the axotomyinduced decrease of ChAT immunoreactivity and activity and enhance the reexpression of $\mathrm{p} 75^{\mathrm{LNGFR}}$.

It is interesting that although adult injured motoneurons readily responded to BDNF, BDNF did not stimulate the ChAT activity or immunoreactivity over the level of nonlesion motoneurons. In addition, systemic and intracerebroventricular administration of BDNF did not influence the ChAT levels of the nonlesioned motoneurons. Previously, we found that in neonatal rats, BDNF had no protective effect on the ChAT activity of lesioned spinal motoneurons, although it was effective in protecting neonatal motoneurons from axotomy-induced cell death (Yan et al., 1993). It is likely that, in neonatal rats, BDNF provides a replacement of target-derived neurotrophic factor(s) for the ax- 
otomized motoneurons for their survival but BDNF is not sufficient for the maintenance of the expression of ChAT. In contrast, axotomized adult motoneurons do not depend on trophic factor for survival but they apparently need trophic factor, such as BDNF, for the maintenance of the expression of ChAT. The dissociation of a protective effect and a neurotransmitter enzyme stimulation effect of BDNF on motoneurons is markedly different from the effects of NGF on its responsive neurons. NGF has been shown to promote neuronal survival and stimulate neurotransmitter enzyme synthesis in normal as well as lesioned sympathetic (Thoenen et al., 1971; Hendry and Campbell, 1976; Kessler and Black, 1980) and medial septal cholinergic neurons (Hefti et al., 1984; Hagg et al., 1989; Higgins et al., 1989). The difference in neurotrophic effects of BDNF and NGF on their responsive neurons could arise from differences in the signal transduction pathways or intrinsic differences in their responsive neurons. It is interesting to note that BDNF stimulates the ChAT activity of cultured motoneurons over controls (Henderson et al., 1993; Wong et al., 1993). Possible explanations for the discrepancy between our data and the in vitro studies include (1) the effect of BDNF on ChAT activity of cultured motoneurons may partially result from its survival-promoting effect on cultured motoneurons (more neurons and therefore more ChAT) and partially result from its effect to prevent the decrease of ChAT activity of cultured motoneurons that are axotomized during the preparation, (2) the differences in the ages of animals studied (embryonic vs postnatal), (3) differences between the in vitro and in vivo environment.

p $75^{\text {LNGFR }}$ is expressed by motoneurons only during development and has largely disappeared by postnatal day 10 in rats (Yan and Johnson, 1988; Ernfors et al., 1989). In adult rats, lesion causes reexpression of $\mathrm{p} 75^{\mathrm{LNGFR}}$ in motoneurons (Ernfors et al., 1989; Wood et al., 1990; Armstrong et al., 1991; Koliatsos et al., 1991). Here we show that in addition to its protective effect on ChAT, BDNF enhances the reexpression of p $75^{\text {LNGFR }}$ in axotomized motoneurons. This enhancement effect of BDNF on the $\mathrm{p} 75^{\mathrm{LNGFR}}$ expression is unexpected since we argued that supplying exogenous BDNF would move the motoneurons back toward their normal, resting, intact state. This is not the case. BDNF attenuates the decrease in ChAT immunoreactivity (normal state), but augments the increase in p $75^{\text {LNGFR }}$ (abnormal state). This indicates that the transduction mechanisms that act on these two parameters in motoneurons are effected very differently by BDNF. The biological role of $p 75^{\text {LNGFR }}$ is not clear at present. The upregulation of its expression following injury by motoneurons and other cells may contribute to the process of regeneration (Johnson et al., 1988). p75 ${ }^{\text {LNGFR }}$ may also mediate effects of BDNF, since it is a BDNF binding protein. The potential role of $p 75^{\text {LNGFR }}$ in mediating the effects of BDNF on normal and lesioned motoneurons may be evaluated in the recently developed p $75^{\text {LNGFR }}$ knock-out mice (Lee et al., 1992).

In an effort to find a route of administration of BDNF that will be most efficient in affecting motoneurons, we compared subcutaneous, intravenous, and intracerebroventricular administration. All three routes of administration attenuated the decrease of ChAT in lesioned facial motoneurons in a dose-dependent fashion. The highest doses of BDNF administered by subcutaneous or intravenous routes resulted in similar maximal effects on lesioned motoneurons. At lower doses, intravenous administration was more efficient. The difference between subcutaneous and intravenous delivery at the lower doses likely resulted from the lower bioavailability of BDNF from a sub- cutaneous bolus injection, and this was apparently compensated for at higher doses of BDNF. Due to the technical difficulties associated with intrathecal administration, in which drug solutions arc introduced into the subarachnoid space, we chose to deliver BDNF via intracerebroventricular administration. Since very little BDNF injected intracerebroventricularly can penetrate brain parenchyma (Yan et al., 1994), the bulk of BDNF should be carried by cerebral spinal fluid through the cerebral ventricular system into the subarachnoid space. Therefore, for application of BDNF to brainstem motoneurons, intracerebroventricular administration should resemble intrathecal administration. Since BDNF administered intracerebroventricularly was able to attenuate the lesion-induced decrease of ChAT immunoreactivity in the facial nucleus in a dose-dependent fashion, this study suggests that intrathecal administration of BDNF will also be effective in affecting spinal and brainstem motoneurons. Axotomized motoneurons can be protected by BDNF via a peripheral mechanism (e.g., mediated by BDNF receptors on nerve terminals and on motor axons), since a small amount of BDNF administered locally is effective. Although it is likely that systemically administered BDNF acts on lesioned motoneurons through such a peripheral mechanism, due to the large quantity of BDNF used for the systemic administration, one cannot completely rule out the possibility that a small amount of circulating BDNF could leak into the brain and protect motoneurons directly. When administered intracerebroventricularly, BDNF may affect the motoneurons by bathing the motor nerves within the subarachnoid space (similar to the peripheral mechanism) or by penetrating into the brain parenchyma from the surface of the brainstem and directly acting on motoneuron cell bodies. It is unlikely that BDNF injected intracerebroventricularly could affect motoneurons systemically because a similar dose of BDNF has no effect if administered systemically.

We found BDNF injected intracerebroventricularly caused animals to lose weight in a dose-dependent manner as shown previously for NGF (Williams, 1991). The wcight loss probably results from reduced food intake (Lapchak and Hefti, 1992; Pelleymounter and Cullen, 1993). Although the underlying mechanism of weight loss by BDNF and NGF injected intracerebroventricularly is not known, it is speculated that direct or indirect activation of the hypothalamus by high dose of BDNF and NGF injected intracerebroventricularly may affect animals' eating behavior (Williams, 1991; Pelleymounter and Cullen, 1993). If the effect of BDNF injected intracerebroventricularly on body weight is mediated by the hypothalamus or other structures adjacent to the ventricles, it may be avoided or reduced by intrathecal administration of BDNF into the lumber or cerebellomedullary cistern. Because of the flow of CSF, the intrathecally administered BDNF would not gain access to brain structures along the ventricles. High doses of BDNF administered intravenously also had a clear negative effect on weight gain. It is possible that peripherally injected BDNF can penetrate into brain areas that lack a blood-brain barrier such as the circumventricular organs (Weindl and Sofroniew, 1978). Whether cells in circumventricular organs express trkB and whether the weight loss caused by intravenous administration of BDNF is mediated by CNS mechanisms remain to be studied.

In summary, we found that adult brainstem and spinal motoneurons express $t r k B$ receptor $m R N A$ and protein. Local, systemic, and intracerebroventricular administration of BDNF effectively attenuated the axotomy-induced decrease of ChAT and enhanced the axotomy-induced reexpression of $p 75^{\text {LNGFR }}$ in adult 
motoneurons. This and other studies provide a strong rationale for the potential clinical use of BDNF for the treatment of motoneuron degenerative diseases, such as ALS.

\section{References}

Acheson A, Barber PA, Alderson RF, Miller FD, Murphy RA (1991) Detection of brain derived neurotrophic factor like activity in fibroblasts and Schwann cells: inhibition by antibodies to NGF. Neuron $7: 265-275$.

Anderson KD, Alderson RF, Altar CA, DiStefano PS, Corcoran TL, Lindsay RM, Wiegand SJ (1993) Distribution of exogenous BDNF and NGF delivered into the brain. Soc Neurosci Abstr 19:662.

Arakawa Y, Sendtner M, Thoenen H (1990) Survival effect of ciliary neurotrophic factor (CNTF) on chick embryonic motoneurons in culture: comparison with other neurotrophic factors and cytokines. J Neurosci 10:3507-3515.

Armstrong DM, Brady R, Hersh LB, Hayes RC, Wiley RG (1991) Expression of choline acetyltransferase and nerve growth factor receptor within hypoglossal motoneurons following nerve injury. J Comp Neurol 304:596-607.

Carroll SL, Silos-Santiago I, Frese SE, Ruit KG, Milbrandt J, Snider WD (1992) Dorsal root ganglion neurons expressing $t r k$ are selectively sensitive to NGF deprivation in utero. Neuron 9:779-788.

Coughlin MD, Boyer DM, Black IB (1977) Embryological development of a mouse sympathetic ganglion in vivo and in vitro. Proc Natl Acad Sci USA 74:3438-3442.

Crews LL, Wigston DJ (1990) The dependence of motoneurons on their target muscle during postnatal development of the mouse. J Neurosci 10:1643-1653.

DiStefano PS, Friedman B, Radziejewski C, Alexander C, Boland P, Schick CM, Lindsay RM, Wiegand SJ (1992) The neurotrophins BDNF, NT-3 and NGF display distinct patterns of retrograde axonal transport in peripheral and central neurons. Neuron 8:893-993.

Ernfors P, Persson H (1991) Developmentally regulated expression of HDNF/NT-3 mRNA in rat spinal cord motoneurons and expression of BDNF mRNA in embryonic dorsal root ganglion. Eur $\mathbf{J}$ Neurosci 3:953-961.

Ernfors P, Henschen A, Olson L, Persson H (1989) Expression of nerve growth factor receptor mRNA is developmentally regulated and increased after axotomy in rat spinal cord motoneurons. Neuron 2:1605-1613

Ernfors P, Merlio J-P, Persson H (1992) Cells expressing mRNA for neurotrophins and their receptors during embryonic rat development. Eur J Neurosci 4:1140-1158.

Fonnum F (1975) A rapid radiochemical method for the determination of choline acetyltransferase. J Neurochem 24:407-409.

Hagg T, Fass-Holmes B, Vahlsing HL, Manthorpe M, Conner JM, Varon S (1989) Nerve growth factor (NGF) reverses axotomy-induced decreases in choline acetyltransferase, NGF receptor and size of medial septum cholinergic neurons. Brain Res 505:29-38.

Hallböök F, Ibáñez CF, Persson H (1991) Evolutionary studies of the nerve growth factor family reveal a novel member abundantly expressed in Xenopus ovary. Neuron 6:845-858.

Hefti F, Dravid A, Hartikka J (1984) Chronic intraventricular injections of nerve growth factor elevate hippocampal choline acetyltransferase activity in adult rats with partial septo-hippocampal lesions. Brain Res 293:305-311.

Hempstead BL, Martin-Zanca D, Kaplan D, Parada LF, Chao MV (1991) High-affinity NGF binding requires coexpression of the $t r k$ proto-oncogene and the low-affinity NGF receptor. Nature 350:678683.

Henderson CE, Camu W, Mettling C, Gouin A, Poulsen K, Karihaloo M, Rullamas J, Evans T, McMahon SB, Armanini MP, Berkemeier L, Philips HS, Rosenthal A (1993) Neurotrophins promote motor neuron survival and are present in embryonic limb bud. Nature 363: 266-270.

Hendry IA, Campbell J (1976) Morphometric analysis of rat superior cervical ganglia after axotomy and nerve growth factor treatment. J Neurocytol 5:351-360.

Higgins GA, Koh S, Chen KS, Gage FH (1989) NGF induction of NGF receptor gene expression and cholinergic neuronal hypertrophy within the basal forebrain of the adult rat. Neuron 3:247-256.
Johnson EM, Rich M, Yip HK (1986) The role of NGF in sensory neurons in vivo. Trends Neurosci 9:33-37.

Johnson EM Jr, Taniuchi M, DiStefano PS (1988) Expression and possible function of nerve growth factor receptors on Schwann cells. Trends Neurosci 1:299-304.

Kaplan DR, Hempstead BL, Martin-Zanca D, Chao MV, Parada LF (1991) The trk proto-oncogene product: a signal transducing receptor for nerve growth factor. Science 252:554-558.

Kessler JA, Black IB (1980) The effects of nerve growth factor (NGF) and antiserum to NGF on the development of embryonic sympathetic neurons in vivo. Brain Res 189:157-168.

Klein R, Conway D, Parada LF, Barbacid M (1990) The trkB tyrosine protein kinase gene codes for a second neurogenic receptor that lacks the catalytic kinase domain. Cell 61:647-656.

Klein R, Jing S, Nanduri V, O'Rourke E, Barbacid M (1991a) The trk proto-oncogene encodes a receptor for nerve growth factor. Cell 65:189-197.

Klein R, Nanduri V, Jing S, Lamballe F, Tapley $P$, Bryant $S$, CordonCordo C, Jones KR, Reichardt LF, Barbacid M (1991b) The trkB tyrosine protein kinase is a receptor for brain-derived neurotrophic factor and neurotrophin-3. Cell 66:395-403.

Koliatsos VE, Crawford TO, Price DL (1991) Axotomy induces nerve growth factor receptor immunoreactivity in spinal motor neurons. Brain Res 549:297-304.

Koliatsos VE, Clatterbuck RE, Winslow JW, Cayouette MH, Price DL (1993) Evidence that brain-derived neurotrophic factor is a trophic factor for motor neurons in vivo. Neuron 10:359-367.

Lamballe F, Klein R, Barbacid M (1991) trk C, a new member of the trk family of tyrosine protein kinases, is a receptor for neurotrophin3. Cell 66:967-979.

Lams BE, Isacson O, Sofroniew MV (1988) Loss of transmitter-associated enzyme staining following axotomy does not indicate death of brainstem cholinergic neurons. Brain Res 475:401-406.

Lapchak P, Hefti F (1992) BDNF and NGF treatment in lesioned rats: effects on cholinergic function and weight gain. Neuroreport 3:405-408.

Lee K-F, Li E, Huber LJ, Landis SC, Sharpe AH, Chao MV, Jaenisch R (1992) Targeted mutation of the gene encoding the low-affinity NGF receptor $\mathrm{p} 75$ leads to deficits in the peripheral sensory nervous system. Cell 69:737-749.

Leibrock J, Lottspeich F, Hohn A, Hofer M, Hengerer B, Masiakowski $\mathrm{P}$, Thoenen H, Barde Y-A (1989) Molecular cloning and expression of brain-derived neurotrophic factor. Nature 341:149-152.

Lindsay RM, Thoenen H, Barde Y-A (1985) Placode and neural crestderived sensory neurons are responsive at early developmental stages to brain-derived neurotrophic factor. Dev Biol 112:319-328.

Maisonpierre PC, Belluscio L, Friedman B, Alderson RF, Wiegand SJ, Furth ME, Lindsay RM, Yancopoulos GD (1990) NT-3, BDNF, and NGF in the developing rat nervous system: parallel as well as reciprocal patterns of expression. Neuron 5:501-509.

Matheson C, Sun J, Radeke MJ, Feinstein SC, Miller JA, Yan Q (1993) Distribution of exogenous neurotrophins in the rat CNS following ICV injection. Soc Neurosci Abstr 19:1305.

Merlio JP, Ernfors P, Jaber M, Persson H (1992) Molecular cloning of rat $t r k \mathrm{C}$ and distribution of cell expressing messenger RNAs for members of the trk family in the rat central nervous system. Neuroscience 51:513-532.

Meyer M, Matsuoka I, Wetmore C, Olson L, Thoenen H (1992) Enhanced synthesis of brain-derived neurotrophic factor in the lesioned peripheral nerve: different mechanisms are responsible for the regulation of BDNF and NGF mRNA. J Cell Biol 119:45-54.

Middlemas DS, Lingberg RA, Hunter T (1991) trkB, a neural receptor protein-tyrosine kinase: evidence for a full-length and two truncated receptors. Mol Cell Biol 11:143-153.

Miyata Y, Kashihara Y, Homma S, Kumo M (1986) Effects of nerve growth factor on the survival and synaptic function of la sensory neurons axotomized in neonatal rats. J Neurosci 6:2012-2018.

Oppenheim RW, Maderdrut JL, Wells DJ (1982) Cell death of motoneurons in the chick embryo spinal cord. VI. Reduction of naturally occurring cell death in the thoracolumbar column of Terni by nerve growth factor. J Comp Neurol 210:174-189.

Oppenheim RW, Qin-Wei Y, Prevette D, Yan Q (1992) Brain-derived neurotrophic factor rescues developing avian motoneurons from cell death. Nature 360:755-757. 
Paxinos G, Watson C (1986) The rat brain in stereotaxic coordinates. Sydney: Academic.

Pelleymounter MA, Cullen MJ (1993) Characteristics of BDNF-induced weight loss. Soc Neurosci Abstr 19:664.

Rodriguez-Tébar A, Dechant G; Barde Y-A (1990) Binding of brainderived neurotrophic factor to the nerve growth factor receptor. Neuron 4:487-492.

Ruit KG, Osborne PA, Schmidt RE, Johnson EM, Snider WD (1990) Nerve growth factor regulates sympathetic ganglion cell morphology and survival in adult mouse. $J$ Neurosci 10:2412-2419.

Schecterson LC, Bothwell M (1992) Novel roles for neurotrophins are suggested by BDNF and NT-3 mRNA expression in developing neurons. Neuron 9:449-463.

Schmalbruch H (1984) Motor neuron death after sciatic nerve section in newborn rats. J Comp Neurol 224:252-258.

Sendtner M, Holtmann B, Kolbeck R, Thoenen H, Barde Y-A (1992) Brain-derived neurotrophic factor prevents the death of motoneurons in newborn rats after nerve section. Nature 360:757-759.

Snider WD, Elliott JL, Yan Q (1992) Axotomy-induced neuronal death during development. J Neurobiol 23:1231-1246.

Soppet D, Escandon E, Maragos J, Middlemas DS, Reid J, Blair SW, Burton LE, Stanton BR, Kaplan DR, Hunter T, Nikolics K, Parada LF (1991) The neurotrophic factors brain-derived neurotrophic factor and neurotrophin-3 are ligands for the $\operatorname{trk} \mathrm{B}$ tyrosine kinase receptor. Cell 65:895-903.

Squinto SP, Stitt TN, Aldrich TH, Davis S, Blanco SM, Radziejewski C, Glass DJ, Masiakowski P, Furth ME, Valenzuela DM, DiStefano PS, Yancopoulos GD (1991) trkB encodes a functional receptor for brain-derived neurotrophic factor and neurotrophin-3 but not nerve growth factor. Cell 65:885-893.

Thoenen H, Barde Y-A (1980) Physiology of nerve growth factor. Physiol Rev 60:1284-1335.

Thoenen H, Angeletti PU, Levi-Montalcini R, Kettler R (1971) Selective induction of tyrosine hydroxylase and dopamine b-hydroxy- lase in rat superior cervical ganglia by nerve growth factor. Proc Natl Acad Sci USA 68:1598-1602.

Weindl A, Sofroniew MV (1978) Neurohormone and circumventricular organs. In: Brain-endocrine interaction. III. Neural hormones and reproduction. 3rd International Symposium, Wütxnuth, 1977, pp 117-137. Basel: Karger.

Williams DB, Windebank AJ (1991) Motor neuron disease (amyotrophic lateral sclerosis). Mayo Clinic Proc 66:54-82.

Williams LR (1991) Hypophagia is induced by intracerebroventricular administration of nerve growth factor. Exp Neurol 113:31-37.

Wong V, Arriaga R, Ip NY, Lindsay RM (1993) The neurotrophins BDNF, NT-3 and NT-4/5, but not NGF, up-regulate the cholinergic phenotype of developing motor ncurons. Eur J Neurosci 5:466-474.

Wood SJ, Pritchard J, Sofroniew MV (1990) Re-expression of nerve growth factor receptor after axonal injury recapitulates a developmental event in motor neurons: differential regulation when regeneration is allowed or prevented. Eur $\mathbf{J}$ Neurosci 2:650-657.

Yan Q, Johnson EM Jr (1988) An immunohistochemical study of the nerve growth factor receptor in developing rats. J Neurosci 8:34813498.

Yan Q, Snider WD, Pinzone JJ, Johnson EM Jr (1988) Retrograde transport of nerve growth factor (NGF) in motoneurons of developing rats: assessment of potential neurotrophic effects. Neuron 1:335-343.

Yan Q, Elliott J, Snider WD (1992) Brain-derived neurotrophic factor rescues spinal motoneurons from axotomy induced cell death. Nature 360:753-755.

Yan Q, Elliott J, Matheson C, Sun J, Zhang L, Mu X, Rex KL, Snider WD (1993) Influences of neurotrophins on mammalian motoneurons in vivo. J Neurobiol 24:1555-1577.

Yan Q, Matheson C, Sun J, Radeke MJ, Feinstein SC, Miller JA (1994) Distribution of the intracerebral ventricularly administered neurotrophins in rat brain and its correlation with the receptor expression. Exp Neurol, in press. 